\title{
CORRIGENDUM
}

\section{FAS-ligand regulates differential activation-induced cell death of human T-helper 1 and 17 cells in healthy donors and multiple sclerosis patients}

\author{
MT Cencioni ${ }^{1,8}$, S Santini ${ }^{2,3,8}$, G Ruocco ${ }^{1,8}$, G Borsellino ${ }^{1}$, M De Bardi', MG Grasso ${ }^{4}$, S Ruggieri ${ }^{5}$, C Gasperini ${ }^{5}$, D Centonze $e^{6,7}$, D Barilä ${ }^{2,3}$, \\ L Battistini ${ }^{1}$ and E Volpe*,1
}

Cell Death and Disease (2015) 6, e1785; doi:10.1038/cddis.2015.164; published online 11 June 2015

Correction to: Cell Death and Disease (2015) 6, e1741; doi:10.1038/cddis.2015.100; published online 7 May 2015

Since the publication of this paper the authors have noted that the affiliation addresses were incorrect. This has now been rectified and the corrected article appears online together with this corrigendum.

The authors would like to apologize for any inconvenience this may have caused.

\footnotetext{
${ }^{1}$ Neuroimmunology Unit, Santa Lucia Foundation, Rome, Italy; ${ }^{2}$ Cell Signaling Unit, Santa Lucia Foundation, Rome, Italy; ${ }^{3}$ Department of Biology, University Tor Vergata, Rome, Italy; ${ }^{4}$ Multiple Sclerosis Centre, Santa Lucia Foundation, Rome, Italy; ${ }^{5}$ Department of Neuroscience 'Lancisi', San Camillo Hospital, Rome, Italy; ${ }^{6}$ Department of Neuroscience, University Tor Vergata, Rome, Italy and ${ }^{7}$ Neuroimmunology and Synaptic Plasticity Unit, Santa Lucia Foundation, Rome, Italy

*Corresponding author: E Volpe, Neuroimmunology Unit, Santa Lucia Foundation, Via del Fosso di Fiorano 64, Rome 00143 , Italy. Tel: +39 06501703094 ; Fax: +39 06501703 326; E-mail: e.volpe@hsantalucia.it

${ }^{8}$ These authors contributed equally to this work.
} 